\title{
THE CRYSTAL CHEMISTRY OF Li-BEARING MINERALS WITH THE MILARITE-TYPE STRUCTURE: THE CRYSTAL STRUCTURE OF END-MEMBER SOGDIANITE
}

\author{
ELENA V. SOKOLOVA* AND FRANK C. HAWTHORNE§ \\ Department of Geological Sciences, University of Manitoba, Winnipeg, Manitoba R3T 2N2, Canada \\ LEONID A. PAUTOV \\ Fersman Mineralogical Museum, Russian Academy of Sciences, Moscow, 117071, Russia
}

\begin{abstract}
The crystal structure of end-member sogdianite from the Dara-i-Pioz alkaline massif, northern Tajikistan, $a$ 10.1240(3), $c$ 14.3198(5) $\AA, V 1271.1(1) \AA^{3}$, space group $P 6 / m c c, Z=2$, has been refined to an $R$ index of $2.0 \%$ using 576 observed $\left(\left|F_{\mathrm{o}}\right|>4 \sigma F\right)$ reflections collected with single-crystal diffractometer with $\mathrm{MoK} \alpha \mathrm{X}$-radiation. Electron-microprobe analysis gives a composition $\left(\mathrm{Zr}_{1.98} \mathrm{Hf}_{002}\right)_{\Sigma 2.00}\left(\mathrm{~K}_{0.99} \mathrm{Na}_{0.01}\right)_{\Sigma 1.00} \mathrm{Li}_{2.97} \mathrm{Si}_{12.01} \mathrm{O}_{30}$. The sogdianite end-member has the typical structure of the double-ring silicates of the milarite structure-type: the $A$ octahedron and $T(2)$ tetrahedron are completely occupied by $\mathrm{Zr}$ and $\mathrm{Li}$, and tetravalent $\mathrm{Zr}$ at the $A$ site induces the lack of $\mathrm{Na}$ at the $B$ site. The simplified chemical formula $\mathrm{Zr}_{2} \mathrm{~K} \mathrm{Li}_{3} \mathrm{Si}_{12} \mathrm{O}_{30}$ corresponds to the ideal end-member formula of sogdianite $\left(\mathrm{Zr}, \mathrm{Ti}^{4+}, \mathrm{Fe}^{3+}, \mathrm{Al}\right)_{2}(\square, \mathrm{Na})_{2} \mathrm{~K}\left[\mathrm{Li}_{3} \mathrm{Si}_{12} \mathrm{O}_{30}\right.$ ] with $\mathrm{Zr}$ dominant at the $A$ site and $\square$ (vacancy) dominant at the $B$ site: $\mathrm{Zr}_{2} \square_{2} \mathrm{~K}\left[\mathrm{Li}_{3} \mathrm{Si}_{12} \mathrm{O}_{30}\right]$.
\end{abstract}

Keywords: sogdianite, milarite-type structure, end-member, crystal chemistry.

SOMMAIRE

Nous avons affiné la structure cristalline d'un échantillon de sogdianite dont la composition est celle du pôle, provenant du complexe alcalin de Dara-i-Pioz, dans la partie nord du Tajikistan, $a$ 10.1240(3), $c$ 14.3198(5) $\AA, V 1271.1(1) \AA^{3}$, groupe spatial $P 6 /$ mcc,$Z=2$, jusqu'à un résidu $R$ de $2.0 \%$ en utilisant 576 réflexions observées $\left(\left|F_{\mathrm{o}}\right|>4 \sigma F\right)$ prélevées sur cristal unique au moyen d'un diffractomètre avec rayonnement $\mathrm{MoK} \alpha$. Une analyse à la microsonde électronique a donné $\left(\mathrm{Zr}_{1.98} \mathrm{Hf}_{002}\right)_{\Sigma 2.00}\left(\mathrm{~K}_{0.99}\right.$ $\left.\mathrm{Na}_{0.01}\right)_{\Sigma 1.00} \mathrm{Li}_{2.97} \mathrm{Si}_{12.01} \mathrm{O}_{30}$. La sogdianite pure possède la structure typique à anneaux doubles de tétraèdres silicatés des membres du groupe de la milarite. Les octaèdres $A$ et les tétraèdres $T(2)$ sont complètement remplis par le $\mathrm{Zr}$ et le $\mathrm{Li}$; la présence du $\mathrm{Zr}$ tétravalent dans le site $A$ est la cause de l'absence de $\mathrm{Na}$ au site $B$. La formule chimique simplifiée, $\mathrm{Zr}_{2} \mathrm{~K} \mathrm{Li}_{3} \mathrm{Si}_{12} \mathrm{O}_{30}$, correspond au pôle idéal de la sogdianite, plus généralement représentée par $\left(\mathrm{Zr} \mathrm{Ti}^{4+}, \mathrm{Fe}^{3+}, \mathrm{Al}\right)_{2}(\square, \mathrm{Na})_{2} \mathrm{~K}\left[\mathrm{Li}_{3} \mathrm{Si}_{12} \mathrm{O}_{30}\right]$, avec $\mathrm{Zr}$ dominant au site $A$ et une lacune ( $\square$ ) dominante au site $B: \mathrm{Zr}_{2} \square_{2} \mathrm{~K}\left[\mathrm{Li}_{3} \mathrm{Si}_{12} \mathrm{O}_{30}\right]$.

Mots-clés: sogdianite, structure du type de la milarite, pôle, cristallochimie.

\section{INTRODUCTION}

Sogdianite from the alkaline massif of Dara-i-Pioz, northern Tajikistan, was described by Dusmatov et al. (1968) as a new mineral with the formula $(\mathrm{K}, \mathrm{Na})_{2} \mathrm{Li}_{2}$ $(\mathrm{Li}, \mathrm{Fe}, \mathrm{Al}, \mathrm{Ti})_{1.8}(\mathrm{Zr}, \mathrm{Ti})\left[\mathrm{Si}_{12} \mathrm{O}_{30}\right]$. Its structure was solved by Bakakin et al. (1975) and then refined both from powder X-ray data (Kabalov et al. 1994) and from single-crystal X-ray data (Cooper et al. 1999). All studies of the crystal structure of sogdianite confirmed its affinity to the milarite structure-type with a general for- mula of ${ }^{[6]} A_{2}{ }^{[9]} B_{2}{ }^{[12]} C^{[18]} D{ }^{[4]} T(2)_{3}{ }^{[4]} T(1)_{12} \mathrm{O}_{30}$ (Forbes et al. 1972). The $T(2)$ tetrahedra and $A$ octahedra connect the $\left[T_{12} \mathrm{O}_{30}\right]$ double-rings along the $c$ axis. The [12]-coordinated $C$ cations are located on the axis of the channels that extend along [001]. In contrast to the sogdianite formula $\mathrm{K}\left(\mathrm{Zr}, \mathrm{Fe}^{3+}, \mathrm{Ti}_{1} \mathrm{Fe}^{2+}\right)_{2}(\mathrm{Li}, \mathrm{Al}, \square)_{3}$ $\left[\mathrm{Si}_{12} \mathrm{O}_{30}\right](\mathrm{Na}, \mathrm{K})$ proposed by Bakakin et al. (1975), Cooper et al. (1999) wrote the formula as $\left(\mathrm{Zr}, \mathrm{Ti}^{4+}, \mathrm{Fe}^{3+}, \mathrm{Al}\right)_{2}(\square, \mathrm{Na})_{2} \mathrm{~K}\left[\mathrm{Li}_{3} \mathrm{Si}_{12} \mathrm{O}_{30}\right]$ ( $\square$ : vacancy) and speculated on a possible formula of the ideal endmember of the sogdianite-sugilite $\left(\mathrm{Fe}^{3+}{ }_{2} \mathrm{Na}_{2} \mathrm{~K}\left[\mathrm{Li}_{3} \mathrm{Si}_{12}\right.\right.$

E-mail address: frank_hawthorne@umanitoba.ca

* Present address: Department of Crystallography and Crystal Chemistry, Faculty of Geology, Moscow State University, Moscow, 119899, Russia 
$\mathrm{O}_{30}$ ]) solid-solution series as $\mathrm{Zr}_{2} \square_{2} \mathrm{~K}\left[\begin{array}{llll}\mathrm{Li}_{3} & \mathrm{Si}_{12} & \mathrm{O}_{30}\end{array}\right]$, the latter having $\mathrm{Zr}$ dominant at the $A$ site and $\square$ dominant at the $B$ site.

At the same time, Na-free sogdianite was found at the Dara-i-Pioz moraine, and here we report crystallographic characterization of the sogdianite end-member of the sogdianite-sugilite solid-solution series: $\mathrm{Zr}_{2} \square_{2}$ $\mathrm{K}\left[\begin{array}{llll}\mathrm{Li}_{3} & \mathrm{Si}_{12} & \mathrm{O}_{30}\end{array}\right]$.

\section{OCCURRENCE}

End-member sogdianite was found in a quartzaegirine aggregate in the moraine of the Dara-i-Pioz glacier (southern slope of the Alai mountain ridge, Garm district, northern Tajikistan). The Dara-i-Pioz alkaline massif is confined to the intersection of the Alai, Gissar, Zeravshan and Turkestan mountain ridges. The glacial valley cuts the upper Dara-i-Pioz massif, which is related to the late Permian - early Triassic Alai intrusive complex. The external part of the complex consists of fine-grained subalkaline biotite granites and represents a second-stage intrusion of the Turkestan complex; its central part consists of alkaline rocks, i.e., syenites and foyaites of the Alai complex, crossed by veins of syenite aplites, pegmatites, quartz and carbonatites.

Usually, the sogdianite end-member occurs in multimineral pseudomorphs after eudialyte. These pseudomorphs also contain bazirite, $\mathrm{BaZrSi}_{3} \mathrm{O}_{9}$ (Pautov \& Khvorov 1998), calcite and relics of eudialyte, and occur in a massive quartz-aegirine aggregate with a small amount of titanite and turkestanite. The sogdianite endmember crystallizes as short prisms $(0.3 \times 0.5 \mathrm{~mm}$; Fig. 1) with numerous inclusions of bazirite. The crys- tals of sogdianite are colorless (in contrast to the pink crystals of sogdianite characterized by Cooper et al. 1999) or white because of inclusions of bazirite, semitransparent, and with a vitreous luster. The forms $\{100\}$ and $\{001\}$ are prevalent. In ultraviolet light, the mineral fluoresces blue. In thin section, the sogdianite end-member is transparent and colorless.

\section{Electron-Microprobe Analysis}

Chemical analysis of the sogdianite end-member (Table 1) was done by atomic absorption ( $\mathrm{Li}, \mathrm{Na}$ and $\mathrm{K})$ and electron-microprobe analysis (for other elements; JCXA-733 electron microprobe; $20 \mathrm{kV}, 21 \mathrm{nA}$ ). Standards were as follows: osumilite USNM 110607 for Si, K, Fe; zircon USNM117288-3 for Zr, Hf; augite USNM122142 for Na (USNM standards from the Smithsonian Museum, Washington, D.C.). In spite of careful preparation of samples, it was very difficult to get pure grains of sogdianite without any trace of bazirite; the presence of bazirite inclusions resulted in a slightly underestimated value of the Li content. On the basis of 30 oxygen atoms $p f u$ (per formula unit), the following chemical formula for the sogdianite endmember was obtained: $\left(\mathrm{Zr}_{1.98} \mathrm{Hf}_{002}\right)_{\Sigma 2.00}\left(\mathrm{~K}_{0.99}\right.$ $\left.\mathrm{Na}_{0.01}\right)_{\Sigma 1.00} \mathrm{Li}_{2.97} \mathrm{Si}_{12.01} \mathrm{O}_{30}$, which approximates very closely to $\mathrm{Zr}_{2} \mathrm{~K} \mathrm{Li}_{3} \mathrm{Si}_{12} \mathrm{O}_{30}$.

\section{Collection of X-Ray Data And CRystal-Structure Refinement}

Single-crystal X-ray-diffraction data for the sogdianite end-member were collected with a Siemens

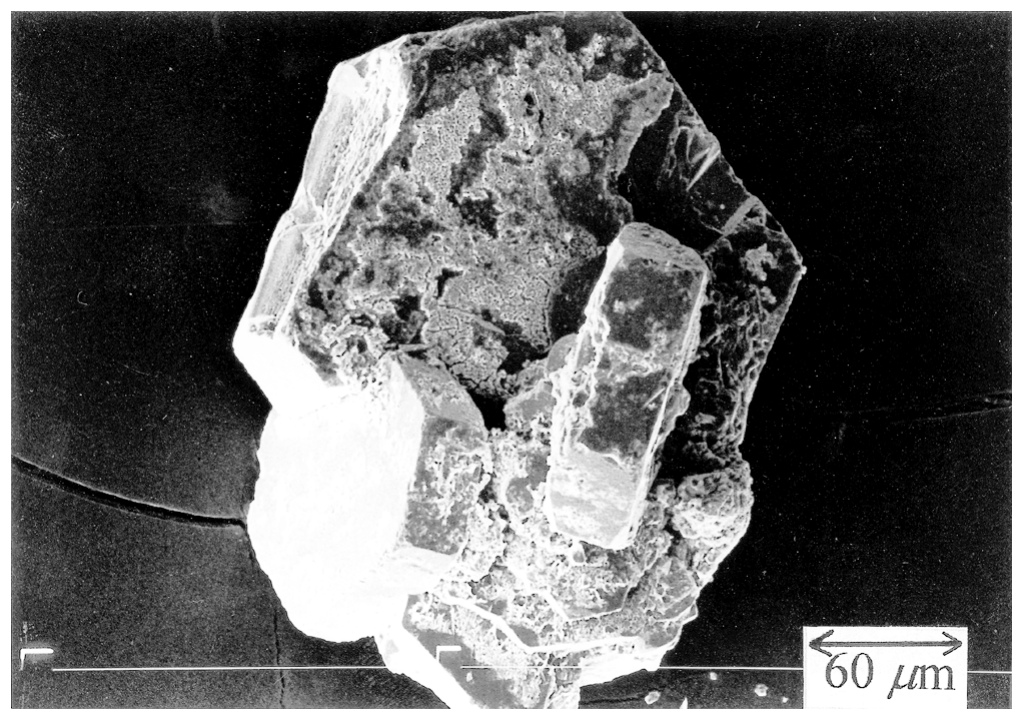

FIG. 1. Image of crystals of end-member sogdianite, as obtained by scanning electron microscopy. The scale bar represents $60 \mu \mathrm{m}$. 
TABLE 1. CHEMICAL COMPOSITION (wt.\%) AND FORMULA UNIT (apfu) OF END-MEMBER SOGDIANITE

\begin{tabular}{|c|c|c|c|c|c|c|c|}
\hline & \multicolumn{2}{|c|}{$\begin{array}{l}\text { End-member }(1)^{* *} \\
\text { sogdianite }\end{array}$} & \multicolumn{2}{|l|}{$(2)^{\star \star}$} & \multicolumn{2}{|c|}{$\begin{array}{l}\text { End-member }(1)^{\star \star \star} \\
\text { sogdianite }\end{array}$} & $(2)^{\star \star \star}$ \\
\hline $\mathrm{SiO}_{2}$ & 68.15 & 68.06 & 68.83 & $\mathrm{Si}$ & 12.01 & 12 & 11.93 \\
\hline $\mathrm{Al}_{2} \mathrm{O}_{3}$ & n.d. * & - & 1.04 & & & & \\
\hline $\mathrm{TiO}_{2}$ & n.d. & - & 2.88 & $K$ & 0.99 & 1 & 1.07 \\
\hline $\mathrm{Fe}_{2} \mathrm{O}_{3}$ & - & - & 4.61 & $\mathrm{Ba}$ & & & 0.02 \\
\hline Feo & 0.02 & - & 1.22 & & & & \\
\hline $\mathrm{HFO}_{2}$ & 0.34 & - & - & $\mathrm{Fe}^{3+}$ & & & 0.60 \\
\hline $\mathrm{ZrO}_{2}$ & 23.09 & 23.26 & 9.78 & $\mathrm{Fe}^{2+}$ & 0.00 & & 0.18 \\
\hline $\mathrm{BaO}$ & n.d. & - & 0.32 & $\mathrm{Hf}$ & 0.02 & & \\
\hline $\mathrm{K}_{2} \mathrm{O}$ & 4.42 & 4.45 & 4.84 & $\mathrm{Zr}$ & 1.98 & 2 & 0.83 \\
\hline $\mathrm{Na}_{2} \mathrm{O}$ & 0.02 & - & 2.81 & $\mathrm{Al}$ & & & 0.21 \\
\hline $\mathrm{Li}_{2} \mathrm{O}$ & 4.19 & 4.23 & 3.73 & $\mathrm{Ti}$ & & & 0.38 \\
\hline \multirow[t]{3}{*}{ Total } & 100.23 & 100.00 & 100.06 & $\mathrm{Na}$ & 0.01 & & 0.94 \\
\hline & & & & $\mathrm{Li}$ & 2.97 & 3 & 2.60 \\
\hline & & & & 0 & 30.00 & 30 & 30.00 \\
\hline
\end{tabular}

* not detected

**(1) calculated based on the ideal formuia $\mathrm{K} \mathrm{Li}{ }_{3} \mathrm{Zr}_{2}\left[\mathrm{Si}_{12} \mathrm{O}_{30}\right]$

(2) taken from Dusmatov et al. (1968)

$P 4$ diffractometer fitted with a CCD detector, using $\mathrm{MoK} \alpha \mathrm{X}$-radiation and an irregular fragment with dimensions $0.03 \times 0.11 \times 0.15 \mathrm{~mm}$. The integrated intensities of 11981 reflections with $\overline{1} \overline{4} \leq h \leq 14, \overline{1} \overline{4} \leq k \leq$ $14, \overline{2} \overline{0} 1 \leq l \leq 20$ were collected up to $2 \theta=59.90^{\circ}$ using $30 \mathrm{~s}$ per frame. The refined unit-cell parameters (Table 2) were obtained from 6150 reflections (I > 10бI). An empirical absorption-correction (SADABS, Sheldrick 1996) was applied.

The atomic coordinates of sogdianite (Cooper et al. 1999) were used as the initial structure-model. On the basis of 576 unique observed reflections, the crystal structure of sogdianite was refined with SHELXL-93 (Sheldrick 1993) to an $R$ of $2.0 \%$ and a GooF of 1.10 for a total of 42 refined parameters. Scattering factors for neutral atoms were taken from the International Tables for X-ray Crystallography (Ibers \& Hamilton 1974). Refined site-occupancies for the $A$ and $T(2)$ sites indicate the presence of $\mathrm{Zr}$ and $\mathrm{Li}$. A final difference electron-density map shows no maximum at the $B$ site, thus confirming the vacancy at this site. Final atom pa-
TABLE 2. MISCELLANEOUS CRYSTAL-STRUCTURE REFINEMENT DATA FOR END-MEMBER SOGDIANITE

\begin{tabular}{|c|c|}
\hline$a(\dot{A})$ & $10.1240(3)$ \\
\hline$c(\hat{\AA})$ & $14.3198(5)$ \\
\hline$V\left(\AA^{3}\right)$ & $1271.1(1)$ \\
\hline Space group & $P 6 / m c c$ \\
\hline$z$ & 2 \\
\hline Absorption coefficient $\left(\mathrm{mm}^{-1}\right)$ & 1.68 \\
\hline$D($ meas $) *$ & $2.78(2) \mathrm{g} / \mathrm{cm}^{3}$ \\
\hline$F(000)$ & 1032 \\
\hline Crystal size (mm) & $0.03 \times 0.11 \times 0.15$ \\
\hline Radiation & MoKa \\
\hline $2 \theta$ range for data collection $(E)$ & 59.82 \\
\hline$R(\mathrm{int})(\%)$ & 3.2 \\
\hline $\begin{array}{l}\text { Reflections collected } \\
F_{0}>4 \mathrm{\sigma} F\end{array}$ & $\begin{array}{l}11927 \\
10453\end{array}$ \\
\hline $\begin{array}{l}\text { Unique reflections } \\
F_{0}>4 \sigma F\end{array}$ & $\begin{array}{l}653 \\
576\end{array}$ \\
\hline Refinement method & $\begin{array}{l}\text { Full-matrix least-squares on } F^{2} \text {; } \\
\text { fixed weights proportional to } 1 / \sigma\left(F_{\mathrm{a}}{ }^{2}\right)\end{array}$ \\
\hline Goodness of fit on $F^{2}$ & 1.100 \\
\hline Final $R$ index $\left[F_{0}>4 \sigma F\right]$ & $R_{1}=2.00$ \\
\hline$R$ index(all data) & $\begin{array}{l}R_{1}=2.37 \\
W R_{2}=5.58 \\
\text { GooF }=1.100\end{array}$ \\
\hline
\end{tabular}

* measured by microflotation.

rameters are given in Table 3, and selected interatomic distances are given in Table 4. Final observed and calculated structure-factors may be obtained from The Depository of Unpublished Data, CISTI, National Research Council, Ottawa, Ontario K1A 0S2, Canada.

\section{Crystal Structure}

Sogdianite is a member of the milarite group (Černý et al. 1980, Hawthorne et al. 1991). In the basic structure of these minerals, pairs of opposing $\left[\mathrm{Si}_{6} \mathrm{O}_{18}\right]$ rings of tetrahedra meld to form $\left[\mathrm{Si}_{12} \mathrm{O}_{30}\right]$ cages that stack to form columns parallel to the $c$ axis (Fig. 2). The columns are arranged at the vertices of a $3^{6}$ net and are linked both horizontally and vertically by additional tetrahedra [formally labeled $T(2)$ in this structure type]. Additional linkage is provided by octahedrally coordinated cations that are labeled $A$. Viewed down the $c$ axis, the structure is virtually identical to that of beryl (Fig. 2a). Viewed along [100] (Fig. 2b), the $\left[\mathrm{Si}_{12} \mathrm{O}_{30}\right]$

TABLE 3. FINAL ATOMIC PARAMETERS FOR END-MEMBER SOGDIANITE

\begin{tabular}{|c|c|c|c|c|c|c|c|c|c|c|}
\hline & $x$ & $y$ & $z$ & $U_{s q}{ }^{*}$ & $U_{11}$ & $U_{22}$ & $U_{33}$ & $U_{23}$ & $U_{13}$ & $U_{12}$ \\
\hline A & $1 / 3$ & $2 / 3$ & $1 / 4$ & $61(1)$ & $59(2)$ & $59(2)$ & $67(2)$ & 0 & 0 & $29(1)$ \\
\hline$c$ & 0 & 0 & $1 / 4$ & $217(3)$ & $207(4)$ & $207(4)$ & $236(7)$ & 0 & 0 & $104(2)$ \\
\hline$T(1)$ & $0.11184(5)$ & $0.35135(5)$ & $0.10941(3)$ & $73(1)$ & $68(2)$ & $80(2)$ & $71(2)$ & $-10(2)$ & $-5(2)$ & $37(2)$ \\
\hline$T(2)$ & 0 & $1 / 2$ & $1 / 4$ & $141(12)$ & $74(26)$ & $146(21)$ & $178(28)$ & 0 & 0 & $37(13)$ \\
\hline$O(1)$ & $0.1246(2)$ & $0.3911(2)$ & 0 & $164(4)$ & $232(10)$ & $197(10)$ & $61(8)$ & 0 & 0 & $105(8)$ \\
\hline$O(2)$ & $0.2179(1)$ & $0.2779(2)$ & $0.13483(8)$ & $138(3)$ & $134(6)$ & $164(7)$ & $164(7)$ & $-3(5)$ & $-5(5)$ & $109(5)$ \\
\hline$O(3)$ & $0.1565(1)$ & $0.4983(1)$ & $0.17173(8)$ & $101(3)$ & $99(5)$ & $102(5)$ & $97(6)$ & $-28(5)$ & $-12(4)$ & $46(5)$ \\
\hline
\end{tabular}

$U_{i j} \times 10^{4}$ 
(a)

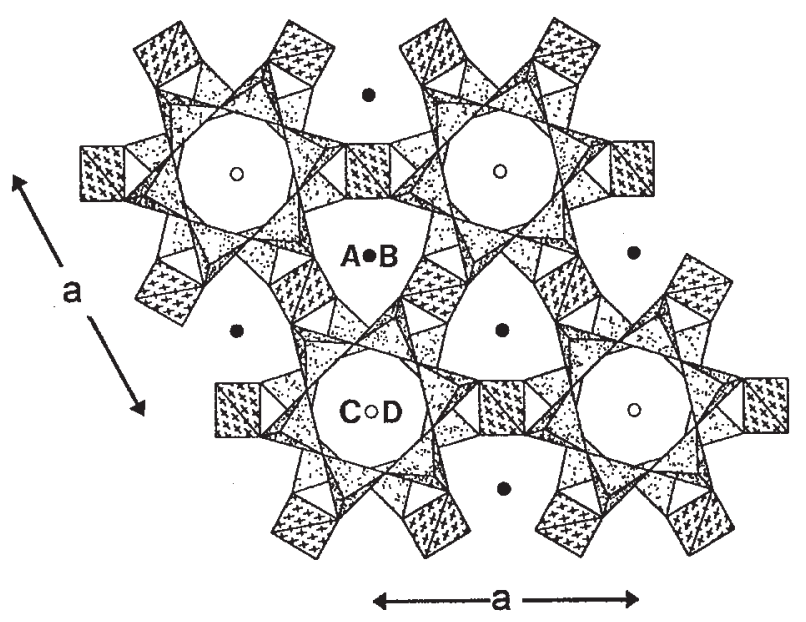

(b)

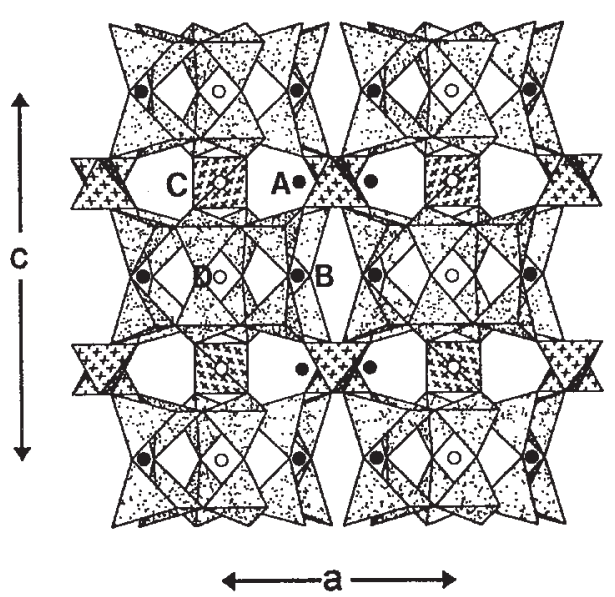

FIG. 2. The crystal structure of the milarite-group minerals: (a) projected onto (001); (b) projected along [100].

cages are apparent. The $B$ site occurs on the six-fold axis between the $\left[\mathrm{Si}_{12} \mathrm{O}_{30}\right]$ cages, and is [9]-coordinated. The $C$ site occurs on the six-fold axis within the $\left[\mathrm{Si}_{12} \mathrm{O}_{30}\right]$ cage, and is [12]-coordinated. The $D$-site oc-

TABLE 4. SELECTED INTERATOMIC DISTANCES $(\AA)$ AND ANGLES $\left({ }^{\circ}\right)$ IN END-MEMBER SOGDIANITE

\begin{tabular}{|c|c|c|c|c|c|}
\hline$A \sim O(3)$ & $x 6$ & $2.077(1)$ & $T(2)-O(3)$ & $x 4$ & $1.947(1)$ \\
\hline$O(3)-O(3) a$ & $\times 3$ & $2.764(2)$ & $\mathrm{O}(3)-\mathrm{O}(3) a$ & $x 2$ & $2.764(2)$ \\
\hline$O(3)-O(3) b$ & $\times 3$ & $2.923(2)$ & $\mathrm{O}(3)-\mathrm{O}(3) \mathrm{e}$ & $x 2$ & $3.185(2)$ \\
\hline$O(3)-O(3) c$ & $x 6$ & $3.029(2)$ & $O(3)-O(3) f$ & $\mathrm{x} 2$ & $3.543(2)$ \\
\hline$<O-O>A$ & & 2.905 & $<0-0>T(2)$ & & 3.164 \\
\hline$O(3)-A-O(3) a$ & $\times 3$ & $83.42(6)$ & $O(3)-T(2)-O(3) a$ & $x^{2}$ & $90.43(7)$ \\
\hline$O(3)-A-O(3) b$ & $x 3$ & $89.45(7)$ & $O(3)-T(2)-O(3) e$ & $x 2$ & $109.72(7)$ \\
\hline$O(3)-A-O(3) c$ & $x 6$ & $93.63(4)$ & $O(3)-T(2)-O(3) f$ & $x^{2}$ & $130.91(7)$ \\
\hline$<O-A-O>$ & & 90.03 & $\langle O-T(2)-O\rangle$ & & 110.35 \\
\hline $\mathrm{C}-\mathrm{O}(2)$ & $\mathrm{x} 12$ & $3.049(1)$ & & & \\
\hline$T(1)-O(1)$ & & $1.607(1)$ & $O(1)-T(1)-O(2)$ & & $110.14(8)$ \\
\hline$T(1)-O(2)$ & & $1.624(1)$ & $O(1)-T(1)-O(2) d$ & & $110.23(9)$ \\
\hline$T(1)-O(2) d$ & & $1.623(1)$ & $O(1)-T(1)-O(3)$ & & $111.25(9)$ \\
\hline$T(1)-O(3)$ & & $1.595(1)$ & $O(2)-T(1)-O 2 d$ & & $104.35(9)$ \\
\hline \multirow[t]{2}{*}{$\langle\pi(1)-\mathrm{O}\rangle$} & & 1.612 & $O(2)-T(1)-O(3)$ & & $110.99(7)$ \\
\hline & & & $O(2) d-T(1)-O(3)$ & & $109.68(6)$ \\
\hline$O(1)-O(2)$ & & $2.649(2)$ & $<O-T(1)-O>$ & & 109.44 \\
\hline$O(1)-O(2) d$ & & $2.649(2)$ & & & \\
\hline$O(1)-O(3)$ & & $2.642(2)$ & & & \\
\hline$O(2)-O(2) d$ & & $2.564(1)$ & & & \\
\hline$O(2)-O(3)$ & & $2.553(2)$ & & & \\
\hline$O(2) d-O(3)$ & & $2.631(2)$ & & & \\
\hline$<0-O>T(1)$ & & 2.631 & & & \\
\hline
\end{tabular}

$a=x, 1-y+x, 1 / 2-z ; \quad b=y-x, y, 1 / 2-z ; c=1-y, 1-y+x, z ; d=x-y, x, z$ $e=-x, 1-y, z ; f=-x, y-x, 1 / 2-z$. curs on the three-fold axis at the same level as the $\left[\mathrm{Si}_{12} \mathrm{O}_{30}\right]$ cages, and is [18]-coordinated. The occupancies of the various sites are given in Table 5 .

In the crystal structure of end-member sogdianite, four sites, $A, C, T(1)$, and $T(2)$, are completely occupied by $\mathrm{Zr}, \mathrm{K}, \mathrm{Si}$ and $\mathrm{Li}$, respectively; the $B$ and $D$ sites are vacant. End-member sogdianite differs from sogdianite as described by Dusmatov et al. (1968) by the absence of $\mathrm{Na}$ at the $B$ site and $\mathrm{Fe}^{3+}, \mathrm{Ti}^{4+}$ and $\mathrm{Fe}^{2+}$ at the $A$ site.

In the end-member sogdianite structure, the $<T(1)-$ O> distance, $1.612 \AA$ (Table 4), is the same as in the sample of sogdianite refined by Cooper et al. (1999). This is the only cation-anion distance that is the same in each structure. The $C$ site is occupied by $\mathrm{K}$, and the $C-\mathrm{O}(2)$ distance is $3.049 \AA$, compared to $3.033 \AA$ (Cooper et al. 1999).

The $A$ site is occupied by $\mathrm{Zr}\left({ }^{[6]} \mathrm{r}=0.72 \AA\right.$; radii from Shannon 1976), and the $A-\mathrm{O}(3)$ distance is $2.077 \AA$ compared to $2.019 \AA$ in sogdianite, where the $A$ site is partly occupied by the smaller cations $\mathrm{Fe}^{3+}\left({ }^{[6]} \mathrm{r}=0.645\right.$ $\AA), \operatorname{Ti}\left({ }^{[6]} \mathrm{r}=0.605 \AA\right)$, and $\mathrm{Al}\left({ }^{[6]} \mathrm{r}=0.535 \AA\right.$ ) (Table 6); the hard-sphere model $A-\mathrm{O}(3)$ distance, $2.080 \AA$, is in

\begin{tabular}{|c|c|c|c|}
\hline Site & Equipoint & C.N. & Occupancy \\
\hline$T(1)$ & $24 m$ & 4 & $\mathrm{Si}, \mathrm{Al}$ \\
\hline$T(2)$ & $6 f$ & 4 & $\mathrm{Li}, \mathrm{Be}, \mathrm{B}, \mathrm{Mg}, \mathrm{Al}, \mathrm{Si}, \mathrm{Mn}^{2+}, \mathrm{Zn}$ \\
\hline$A$ & $4 c$ & 6 & $\mathrm{Al}, \mathrm{Fe}^{3+}, \mathrm{Sn}^{4+}, \mathrm{Mg}, \mathrm{Zr}, \mathrm{Fe}^{2+}, \mathrm{Ca}, \mathrm{Na}, \mathrm{Y}, \mathrm{REE}$ \\
\hline$B$ & $4 d$ & 9 & $\mathrm{Na}, \mathrm{H}_{2} \mathrm{O}, \mathrm{\square}, \mathrm{Ca}$ ?, $\mathrm{K}$ \\
\hline C & 2a & 12 & $\mathrm{~K}, \mathrm{Na}, \mathrm{Ba}, \mathrm{D}, \mathrm{Ca} ?$ \\
\hline D & $2 b$ & 18 & $\square, ?$ \\
\hline
\end{tabular}


TABLE 6. ASSIGNED SITE-POPULATIONS (apfu) AND CALCULATED AND OBSERVED DISTANCES FOR Li- AND Zn-BEARING MINERALS OF THE MILARITE-TYPE STRUCTURE

\begin{tabular}{|c|c|c|c|c|c|c|c|}
\hline \multirow[t]{2}{*}{ Mineral } & \multicolumn{3}{|c|}{ A site } & \multirow{2}{*}{$\frac{B \text { site }}{\text { Site-population }}$} & \multicolumn{3}{|c|}{$T(2)$ site } \\
\hline & Site-population & $\langle A-\mathrm{O}\rangle_{\text {calc }} *$ & $\langle A-O\rangle_{\text {obs }}$ & & Site-population & $\langle T(2)-O\rangle_{\text {calc }}{ }^{*}$ & $\langle T(2)-O\rangle_{\text {obs }}$ \\
\hline Sugilite $^{1}$ & $\mathrm{Fe}^{3+}{ }_{1.66} \mathrm{Al}^{3+}{ }_{0.34}$ & 1.970 & 1.972 & $\square_{1.02} \mathrm{Na}_{0.98}$ & $\mathrm{Li}_{3}$ & 1.950 & 1.970 \\
\hline Brannockite ${ }^{1}$ & $\mathrm{Sn}_{2}^{4+}$ & 2.050 & 2.013 & $\square_{2.0}$ & $\mathrm{Li}_{3}$ & 1.950 & 1.922 \\
\hline Sogdianite ${ }^{2}$ & $\mathrm{Zr}_{0.76} \mathrm{Fe}^{3+}{ }_{0.73} \mathrm{Ti}_{0.38} \mathrm{Al}_{0.13}$ & 2.030 & 2.019 & $\square_{1.15} N a_{0.85}$ & $\mathrm{Li}_{3}$ & 1.950 & 1.957 \\
\hline Sogdianite ${ }^{3}$ & $\mathrm{Zr}_{2}$ & 2.080 & 2.077 & $\square_{2.0}$ & $\mathrm{Li}_{3}$ & 1.950 & 1.947 \\
\hline Dusmatovite $^{4}$ & $\mathrm{Mn}^{2+}{ }_{1.52} \mathrm{Zr}_{0.24} \mathrm{Y}_{0.24}$ & 2.180 & 2.120 & $\square_{1,0} \mathrm{Na}_{0,64} \mathrm{~K}_{0,35}$ & $\mathrm{Zn}_{2.28} \mathrm{Li}_{0.72}$ & 1.960 & 1.971 \\
\hline Darapiosite $^{5}$ & $\mathrm{Mn}^{2+}{ }_{1.47} \mathrm{Zr}_{0.28} \mathrm{Y}_{0.22} \mathrm{Mg}_{0.03}$ & 2.180 & 2.151 & $\mathrm{Na}_{1.22} \mathrm{~K}_{0.36} \square_{0.42}$ & $\mathrm{Li}_{1.54} \mathrm{Zn}_{1.15} \mathrm{Fe}^{2+}{ }_{0.31}$ & 1.950 & 1.976 \\
\hline Shibkovite ${ }^{6}$ & $\mathrm{Ca}_{1.26} \mathrm{Mn}^{2+}{ }_{0.40} \mathrm{Na}_{0.34}$ & 2.330 & 2.300 & $\square_{0.74} K_{1.26}$ & $\mathrm{Zn}_{3}$ & 1.960 & 1.959 \\
\hline
\end{tabular}

*Calculated by summing the constituent ionic radii; values from Shannon (1976); $O=O(3)$;

' Armbruster \& Oberhänsli (1988); ${ }^{2}$ Cooper et al. (1999); ${ }^{3}$ This paper; ${ }^{4}$ Sokolova \& Pautov (1995); ${ }^{5}$ Ferraris et al. (1999);

${ }^{6}$ Sokolova et al. (1999).

TABLE 7. BOND-VALENCE ( $V u$ ) CALCULATIONS AROUND O(3) FOR LI- AND Zn-BEARING MINERALS OF THE THE MILARITE-TYPE STRUCTURE

\begin{tabular}{lccccc}
\hline Mineral & $A^{*}$ & $B^{* *}$ & $T(1)^{* *}$ & $T(2)^{*}$ & $\Sigma O(3)$ \\
\hline Sugilite & 0.50 & 0.08 & 1.14 & 0.25 & 1.97 \\
Brannockite & 0.67 & 0 & 1.14 & 0.25 & 2.06 \\
Sogdianite & 0.60 & 0.03 & 1.10 & 0.25 & 1.98 \\
Sogdianite & 0.67 & 0 & 1.08 & 0.25 & 2.00 \\
Dusmatovite & 0.39 & 0.03 & 1.12 & 0.44 & 1.96 \\
Darapiosite & 0.40 & 0.04 & 1.10 & 0.37 & 1.91 \\
Shibkovite & 0.31 & 0.05 & 1.11 & 0.50 & 1.97 \\
\hline
\end{tabular}

"Pauling's second rule was used to calculate the bond valence from the $A$ and $T(2)$ cations around $O(3)$;

k* bond-valence curves for $\mathrm{Na}$ and Si from Brown \& Altermatt (1985) were used.

close agreement with the observed value of $2.077 \AA$. Hawthorne et al. (1991) showed that there is a close correlation between $\langle A-\mathrm{O}\rangle$ and the constituent-cation radius of the $A$-group cations: a linear model with a correlation coefficient of 0.983 and the form $\langle A-\mathrm{O}\rangle=$ $1.311+1.066\left\langle\mathrm{r}_{\mathrm{A}}\right\rangle$ was reported for the milarite-group minerals $\left(\left\langle\mathrm{r}_{\mathrm{A}}\right\rangle=\right.$ mean radius of the constituent $A$ cations). Hawthorne et al. (1991) also reported the possible existence of two distinct correlations. Additional data, recently obtained for darapiosite, dusmatovite $(\mathrm{Mn}, \mathrm{Zr}, \mathrm{Y})_{2}(\square, \mathrm{Na}, \mathrm{K})_{2} \mathrm{~K}(\mathrm{Zn}, \mathrm{Li})_{3}\left[\mathrm{Si}_{12} \mathrm{O}_{30}\right]$ (Sokolova \& Pautov 1995, Pautov et al. 1996) and shibkovite $(\mathrm{Ca}, \mathrm{Mn}, \mathrm{Na})_{2}(\mathrm{~K})_{2} \mathrm{~K} \mathrm{Zn}_{3}\left[\mathrm{Si}_{12} \mathrm{O}_{30}\right]$ (Pautov et al. 1998, Sokolova et al. 1999) support the existence of two distinct correlations. Furthermore, Ferraris et al. (1999) proposed a separate correlation for the Li-bearing minerals of the milarite group (sugilite, brannockite, sogdianite, and darapiosite): $\langle A-\mathrm{O}\rangle=1.38(5)+0.93(7)$ $\left\langle\mathrm{r}_{\mathrm{A}}\right\rangle$. For Li- and Zn-bearing minerals of the milarite group (Table 7), addition of our data on the end-member sogdianite structure and sogdianite (Cooper et al. 1999) produces a refined correlation: $\langle A-\mathrm{O}\rangle=1.411+$ $0.901\left\langle\mathrm{r}_{\mathrm{A}}\right\rangle$, with $R^{2}=0.974$ (Fig. 2). This equation fits the correlations reported by Ferraris et al. (1999) and Hawthorne et al. (1991) within the estimated standard deviations. Both Na-free minerals, brannockite and sogdianite (Table 7), deviate from linearity by approximately the same value (Fig. 3). We believe that this deviation results from the common feature of both structures, the vacancy dominant at the $B$ site. Cooper et al. (1999) divided the Li-bearing members of the milarite group into two subgroups: (1) those with a vacancy at the $B$ site, and (2) those with $(\mathrm{Na}, \mathrm{K})$ at the $B$ site. There is a third Li-bearing mineral with a vacancy at the $B$ site, berezanskite $\mathrm{Ti}^{4+}{ }_{2} \square_{2} \mathrm{~K}\left[\mathrm{Li}_{3} \mathrm{Si}_{12} \mathrm{O}_{30}\right.$ ] (Pautov \& Agakhanov 1997); its structure is still unrefined.

\section{Coupled Substitution of Cations in Li-Bearing Minerals of the Milarite Group}

The shorter $T(2)-\mathrm{O}(3)$ distance in end-member sogdianite compared to that in sogdianite (Cooper et al.

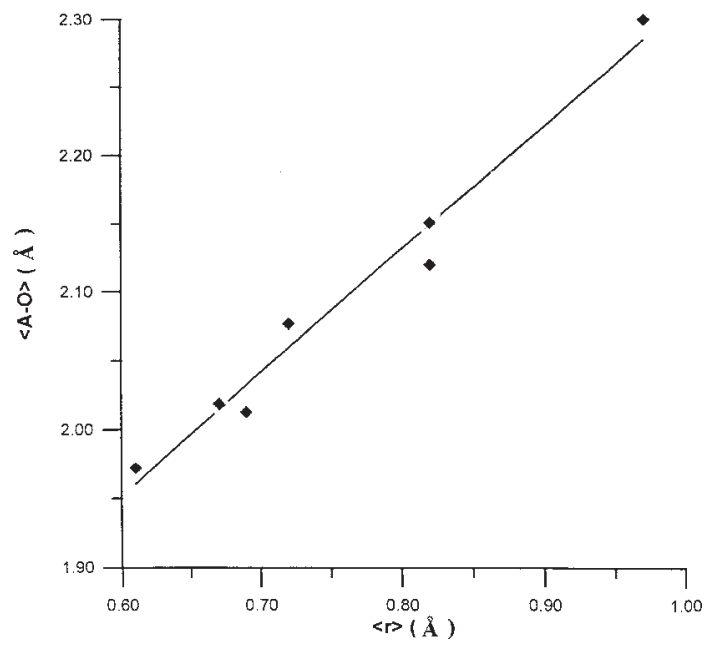

FIG. 3. Variation in $\langle A-\mathrm{O}\rangle$ as a function of constituent-cation radius at the $A$ site for $\mathrm{Li}$ - and $\mathrm{Zn}$-bearing minerals having the milarite-type structure. 
1999) results from the necessary bond-valence requirements at the $\mathrm{O}(3)$ site. The $\mathrm{O}(3)$ anion receives bondvalence from the $A, B, T(1)$ and $T(2)$ cations (Table 7). With increasing bond-valence at the $A$ site, the bond valence at the $B$ and $T(2)$ sites should decrease. In the structure of end-member sogdianite, there is no cation at the $B$ site, and thus the increase in bond-valence $(0.67$ $v u$, valence units, for end-member sogdianite compared with $0.60 v u$ for sogdianite) compensates for the lack of bond-valence incident from the $B$ site. A small decrease in the $T(2)-\mathrm{O}$ bond slightly increases the bond-valence to $\mathrm{O}(3)$ and compensates for the vacancy at the $B$ site. The same dependence of the $T(2)-\mathrm{O}$ bond on the $B$-site population for sugilite and brannockite has been emphasized by Hawthorne et al. (1991). In sugilite, the <T(2)O> bond-length is $1.970 \AA\left(\square_{1.02} \mathrm{Na}_{0.98}\right)$, whereas in brannockite, the $\langle T(2)-\mathrm{O}\rangle$ distance is $1.922 \AA$ ( $\square$ dominant at the $B$ site) (Table 6). Of course, this effect is less pronounced in sogdianite crystals because of a smaller difference of $A$-cation bond-valence compared to sugilite $\left(A=\mathrm{Fe}^{3+}{ }_{1.66} \mathrm{Al}^{3+}{ }_{0.34}\right)$ and brannockite $(A=$ $\mathrm{Sn}^{4+}{ }_{2}$ ).

\section{On the Isomorphous Series Sugilite-Sogdianite}

In accordance with Armbruster \& Oberhänsli (1988), the $a$ and $c$ parameters of sogdianite increase as both the common edge between the $T(2)$ tetrahedron and the $A$ octahedron and the $C-\mathrm{O}$ bond length become longer: $a=10.1240(3), c=14.3198(5) \AA, V=1271.1(1) \AA^{3}$ for end-member sogdianite versus $a=10.053(1), c=$ 14.211(2) $\AA, V=1243.8(4) \AA^{3}$ for sogdianite (Cooper et al. 1999).

A linear correlation of cell parameters versus chemical composition has been established recently for the sugilite-sogdianite isomorphous series (Pautov et al. 2000). More than 50 samples from Dara-i-Pioz have been analyzed by electron-microprobe analysis and Xray powder diffraction, and reveal a continuous sugilitesogdianite solid-solution series. The data confirm the existence of ideal end-member sogdianite. Table 8 presents revised end-member formulae for $\mathrm{Li}$ - and $\mathrm{Zn}$-bearing minerals of the milarite-type structure.

\section{ACKNOWLEDGEMENTS}

The authors thank Pavel V. Khvorov, V.Yu. Karpenko, and A.A. Agakhanov for assistance during field trips, E. Yarosevich for kindly providing standards (Smithsonian Museum, Washington, D.C.) for the electron-microprobe analyses, and Andy Mitchell and an anonymous referee for their comments on this paper. E.V.S. benefitted from grant 99-05-39019, L.A.P. from grant 98-05-64560 from the Russian Fund for Basic Research, and F.C.H. was supported by major equipment, research and major-facilities access grants from the Natural Sciences and Engineering Research Council of Canada.
TABLE 8. END-MEMBER FORMULAE FOR Li- AND Zn-BEARING MINERALS WITH THE MILARITE-TYPE STRUCTURE

\begin{tabular}{llllll}
\hline & $\mathrm{A}$ & $\mathrm{B}$ & $\mathrm{C}$ & $T(2)$ & $T(1)$ \\
\hline Sogdianite & $\mathrm{Zr}_{2}$ & $\square_{2}$ & $\mathrm{~K}$ & $\mathrm{Li}_{3}$ & $\mathrm{Si}_{12}$ \\
Brannockite & $\mathrm{Sn}_{2}$ & $\square_{2}$ & $\mathrm{~K}$ & $\mathrm{Li}_{3}$ & $\mathrm{Si}_{12}$ \\
Berezanskite & $\mathrm{Ti}_{2}$ & $\square_{2}$ & $\mathrm{~K}$ & $\mathrm{Li}_{3}$ & $\mathrm{Si}_{12}$ \\
Darapiosite & $\mathrm{Mn}^{2+} \mathrm{Zr}$ & $\mathrm{Na}_{2}$ & $\mathrm{~K}$ & $\mathrm{Li}_{3}$ & $\mathrm{Si}_{12}$ \\
Sugilite & $\mathrm{Fe}^{3+}{ }_{2}$ & $\mathrm{Na}_{2}$ & $\mathrm{~K}$ & $\mathrm{Li}_{3}$ & $\mathrm{Si}_{12}$ \\
Dusmatovite & $\mathrm{Mn}^{2+}$ & $\square \mathrm{Na}$ & $\mathrm{K}$ & $\mathrm{Zn}_{3}$ & $\mathrm{Si}_{12}$ \\
Shibkovite & $\mathrm{Ca}_{2}$ & $\square \mathrm{K}$ & $\mathrm{K}$ & $\mathrm{Zn}_{3}$ & $\mathrm{Si}_{42}$ \\
\hline
\end{tabular}

\section{REFERENCES}

ARMbruster, T. \& OBERHÄNSLI, R. (1988): Crystal chemistry of double-ring silicates: structures of sugilite and brannockite. Am. Mineral. 73, 595-600.

BaKakin, V.V., Balko, V.P. \& Solovyeva, L.P. (1975): Crystal structure of milarite, armenite, and sogdianite. Sov. Phys. Crystallogr. 19, 460-462.

Brown, I.D. \& AltermatT, D. (1985): Bond-valence parameters obtained from a systematic analysis of the inorganic crystal structure database. Acta Crystallogr. B41, 244-247.

Černy, P., Hawthorne, F.C. \& Jarosewich, E. (1980): The crystal chemistry of milarite. Can. Mineral. 18, 41-57.

Cooper, M.A., Hawthorne, F.C. \& Grew, E.S. (1999): The crystal chemistry of sogdianite, a milarite-group mineral. Am. Mineral. 84, 764-768.

Dusmatov, V.D., Yefimov, A.F., Katayeva, M.E., Khoroshilova, L.A. \& Yanulov, K.P. (1968): Sogdianite, a new mineral. Dokl. Acad. Sci. USSR 182, 137-139.

Ferraris, G., Prencipe, M., Pautov, L.A. \& Sokolova, E.V. (1999): Crystal structure of darapiosite and comparison with $\mathrm{Li}$ - and $\mathrm{Zn}$-bearing minerals of the milarite group. Can. Mineral. 37, 769-774.

Forbes, W.C., BAuR, W.H. \& KHAN, A.A. (1972): Crystal chemistry of milarite-type minerals. Am. Mineral. 57, 463-472.

Hawthorne, F.C., Kimata, M., Černý, P., Ball, N., Rossman, G.R. \& GRICE, J.D. (1991): The crystal chemistry of the milarite-group minerals. Am. Mineral. 76, 18361856.

IBers, J.A. \& Hamilton, W.C., eds. (1974): International Tables for X-ray Crystallography IV. Kynoch Press, Birmingham, U.K.

Kabalov, Yu.K., Sokolova, E.V. \& Pautov, L.A. (1994): More precise determination of the crystalline structure of sogdianite by the Rietveld method. Phys. Dokl. 38, 435437.

Pautov, L.A. \& Agakhanov, A.A. (1997): Berezanskite $\mathrm{KLi}_{3} \mathrm{Ti}_{2} \mathrm{Si}_{12} \mathrm{O}_{30}$, a new mineral. Zap. Vser. Mineral. Obshchest. 126(4), 75-80 (in Russ.). 
\& Sokolova, E.V. (1998): Shibkovite, a new mineral of milarite group. Zap. Vser. Mineral. Obshchest. 127(4), 89-94 (in Russ.).

\& IGNATENKo, K.I. (1996):

Dusmatovite, a new mineral of milarite group. Vestnik Mosk. Univ., Ser. 4 Geol. N2, 54-60 (in Russ.).

\& Khvorov, P.V. (1998): Bazirite from Tajikistan. Zap. Vser. Mineral. Obshchest. 127(1), 80-83 (in Russ.).

, Muftakhov, V.A. \& Agakhanov, A.A. (2000): Sogdianite and sugilite from Dara-i-Pioz massif (Tajikistan). Zap. Vser. Mineral. Obshchest. 129(3), 66-79 (in Russ.).

SHANNON, R.D. (1976): Revised effective ionic radii and systematic studies of interatomic distances in halides and chalcogenides. Acta Crystallogr. A32, 751-767.
SHELDRICK, G.M. (1993): SHELXTL. An Integrated System for Solving, Refining and Displaying Crystal Structures from Diffraction Data ( ${ }^{\text {rd }}$ revision). Univ. of Göttingen, Göttingen, Germany.

(1996): SADABS User Guide, Univ. of Göttingen, Göttingen, Germany.

SoKolova, E.V. \& PAutov, L.A. (1995): Crystal structure of dusmatovite. Phys. Dokl.. 40, 607- 610.

Rybakov, V.B. \& Pautov, L.A. (1999): Crystal structure of shibkovite. Dokl. Earth Sci. 369A, 1288-1291.

Received February 9, 2000, revised manuscript accepted May 19, 2000. 